\title{
Dental defects associated with neonatal symptomatic hypocalcaemia
}

\author{
L. STIMMLER, G. J. A. I. SNODGRASS, and EILEEN JAFFE \\ From the Departments of Paediatrics and Dentistry, Guy's Hospital, London
}

\begin{abstract}
Stimmler, L., Snodgrass, G. J. A. I., and Jafie, E. (1973). Archives of Disease in Childhood, 48, 217. Dental defects associated with neonatal symptomatic hypocalcaemia. 12 children who had had hypocalcaemic convulsions between the 5th and 10th day of life were followed for 2 to 5 years. All 12 children had serious abnormalities of enamel of the canine and molar teeth resulting in progressive destruction of these teeth.
\end{abstract}

When hypocalcaemia occurs in term newborn infants, this is almost always in infants fed on cow's milk preparations. These infants present clinically with convulsion-like movements of the limbs during the period between the fifth and tenth day of life. The incidence of symptomatic hypocalcaemia varies between $1: 200$ to $1: 100$ of all infants born. Asymptomatic hypocalcaemia is easily controlled and the condition appears to be self limited to a period of 3 to 4 days.

We wish to report that structural defects occur in the primary dentition of all children so far examined who have suffered from neonatal symptomatic hypocalcaemia.

\section{Subjects}

Twelve infants who developed hypocalcaemic tetany have been examined regularly since birth, for up to 4 years (Table I). Soon after birth all these infants had 'convulsion-like' movements and their plasma calcium values ranged from 3.5 to $7.5 \mathrm{mg} / 100 \mathrm{ml}$, compared to the normal range in breast-fed infants of 8.3 to

Received 30 June 1972.
$10.6 \mathrm{mg} / 100 \mathrm{ml}$. They had all been fed on cow's milk preparations - 9 on an evaporated milk (Carnation) (which was the prevalent feed at Guy's Hospital at that time) and 3 on a dried milk (Ostermilk).

Similar lesions were seen in the primary canines and molar teeth of each child who had suffered neonatal hypocalcaemic tetany (Fig. 1). These changes were sometimes observed shortly after the teeth had erupted, but usually became more noticeable within a few months of eruption. In the canines (Fig. 1, b and d), the lesions showed a band-like loss of enamel in the incisal third of the crown, sometimes with exposure of dentine and sometimes sparing the enamel on the tip of the cusp. The first primary molars (Fig. 1a, c, d, e, and f) were the most severely affected teeth. In all cases they had a brown band of hypoplastic enamel covering the occlusal surfaces between the sharp-pointed, well-calcified white cusps. Sometimes there was loss of enamel on the buccal surfaces (Fig. 1d and e). The second primary molars (Fig. la and d) were less severely affected and the lesions were sited nearer the cervical margins of the crowns. Many lesions were difficult to describe accurately as they were affected by decay or fractures of enamel, resulting in exposure of dentine. The earliest age at which lesions were observed was 15 months, the time of eruption of the first deciduous

TABLE I

Infants with neonatal tetany

\begin{tabular}{|c|c|c|c|c|c|c|c|c|c|c|c|c|}
\hline Case no. & 1 & 2 & 3 & 4 & 5 & 6 & 7 & 8 & 9 & 10 & 11 & 12 \\
\hline $\begin{array}{l}\text { Feed } \\
\text { Plasma calcium (mg/100 ml) } \\
\text { Plasma phosphorus }(\mathrm{mg} / 100 \mathrm{ml}) \\
\text { Age at time of convulsion }(\mathrm{dy}) \\
\text { Dental enamel }\end{array}$ & $\begin{array}{c}\text { Oster- } \\
\text { milk } \\
6 \cdot 6 \\
8 \cdot 0 \\
10 \\
\text { Hypo- } \\
\text { plasia }\end{array}$ & $\begin{array}{c}\text { Carna- } \\
\text { tion } \\
5 \cdot 2 \\
6 \\
\text { Hypo- } \\
\text { plasia }\end{array}$ & $\begin{array}{c}\text { Carna- } \\
\text { tion } \\
5 \cdot 5 \\
7 \\
7 \\
\text { Hypo- } \\
\text { plasia }\end{array}$ & $\begin{array}{c}\text { Carna- } \\
\text { tion } \\
4 \cdot 0 \\
- \\
5 \\
\text { Hypo- } \\
\text { plasia }\end{array}$ & $\begin{array}{c}\text { Carna- } \\
\text { tion } \\
5 \cdot 7 \\
8- \\
8 \\
\text { Hypo- } \\
\text { plasia }\end{array}$ & $\begin{array}{c}\text { Carna- } \\
\text { tion } \\
6 \cdot 3 \\
6 \\
6 \\
\text { Hypo- } \\
\text { plasia }\end{array}$ & $\begin{array}{l}\text { Carna- } \\
\text { tion } \\
7 \cdot 1 \\
10 \cdot 2 \\
6 \\
\text { Hypo- } \\
\text { plasia }\end{array}$ & $\begin{array}{c}\text { Carna- } \\
\text { tion } \\
7 \cdot 5 \\
10 \\
\text { Hypo- } \\
\text { plasia }\end{array}$ & $\begin{array}{c}\text { Carna- } \\
\text { tion } \\
5 \cdot 9 \\
- \\
8 \\
\text { Hypo- } \\
\text { plasia }\end{array}$ & $\begin{array}{c}\text { Carna- } \\
\text { tion } \\
6 \cdot 4 \\
7 \\
7 \\
\text { Hypo- } \\
\text { plasia }\end{array}$ & $\begin{array}{c}\text { Oster- } \\
\text { milk } \\
6 \cdot 6 \\
6 \\
\text { Hypo- } \\
\text { plasia }\end{array}$ & 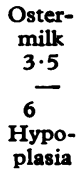 \\
\hline
\end{tabular}



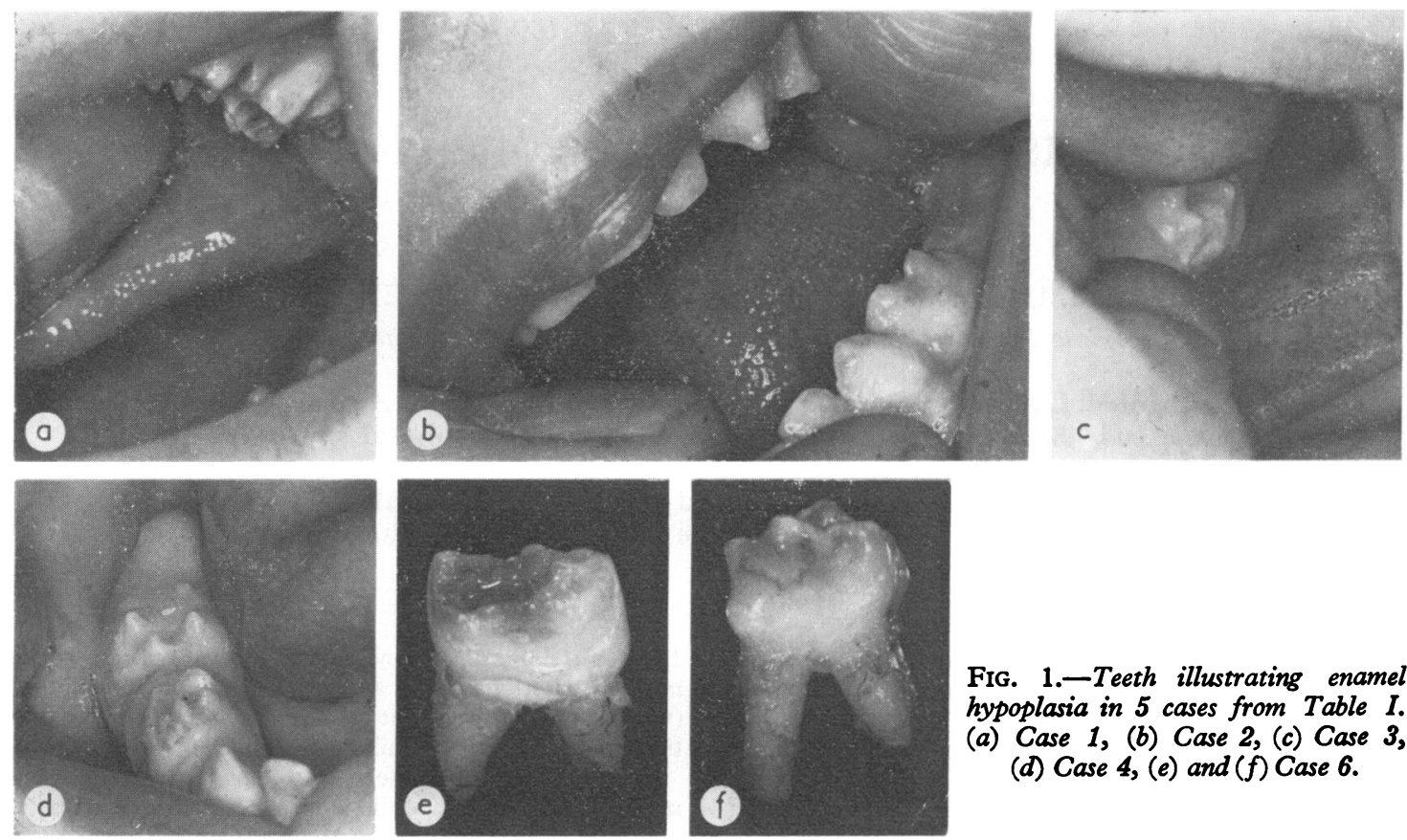

FIG. 1.-Teeth illustrating enamel hypoplasia in 5 cases from Table $I$. (a) Case 1, (b) Case 2, (c) Case 3, (d) Case 4, (e) and (f) Case 6.

molars. The two oldest children in this series, aged 3 and 4 years, respectively, also had severe caries.

In 1969 , a study was performed on serum calcium levels of asymptomatic infants in the first week of life. Later, the teeth were examined in 6 patients in whom serum calcium levels of less than $7.5 \mathrm{mg} / 100 \mathrm{ml}$ had been found (Table II). Of these, 1 patient had marked enamel hypoplasia; 2 had mild irregularities (e.g. unusually pointed first molar cusps); and 3 had normal teeth. It should be emphasized that this group was studied on the basis of their levels of serum calcium and not according to the presence of tetany. In addition, we have examined 250 children between the ages of 2 and 6 years : 100 of these infants were breast fed and showed no enamel abnormalities. 3 of the children who had been bottle fed showed lesions identical to those associated with hypocalcaemic tetany. None of these gave a history of hypocalcaemic tetany, nor were there any records of their serum calcium levels during the first week of life.

\section{Discussion}

Hypocalcaemic tetany in infants fed with either dried or evaporated cow's milk preparations is seen only in the first or second week of life. In the cases presented here, the hypocalcaemia was treated with intravenous or oral calcium gluconate. Serum calcium levels above $8 \mathrm{mg} / 100 \mathrm{ml}$ were obtained and maintained within 24 hours of the diagnosis. Therefore, it is likely that low calcium levels were present for only a few days in each case. Nevertheless, this transient hypocalcaemia seems to be associated with a defect of the enamel which results in severe loss of tooth substance within 12

TABLE II

Infants with hypocalcaemia without tetany

\begin{tabular}{|c|c|c|c|c|c|c|}
\hline Case no. & 13 & 14 & 15 & 16 & 17 & 18 \\
\hline $\begin{array}{l}\text { Feed } \\
\text { Plasma calcium }(\mathrm{mg} / 100 \mathrm{ml}) \\
\text { Plasma phosphorus }(\mathrm{mg} / 100 \mathrm{ml}) \\
\text { Dental enamel }\end{array}$ & $\begin{array}{l}\text { Carnation } \\
6 \cdot 8 \\
8 \cdot 9 \\
\text { Normal }\end{array}$ & $\begin{array}{c}\text { Carnation } \\
6 \cdot 9 \\
9 \cdot 9 \\
\text { Hypoplasia }\end{array}$ & $\begin{array}{l}\text { SMA } \\
6 \cdot 7 \\
9 \cdot 0 \\
\text { Irregular } \\
\text { enamel }\end{array}$ & $\begin{array}{l}\text { Carnation } \\
7 \cdot 0 \\
\text { Normal }\end{array}$ & $\begin{array}{l}\text { Carnation } \\
7 \cdot 4 \\
7 \cdot 8 \\
\text { Normal }\end{array}$ & $\begin{array}{c}\text { Carnation } \\
6 \cdot 7 \\
\text { Irregular } \\
\text { enamel }\end{array}$ \\
\hline
\end{tabular}


months of the teeth appearing in the mouth. It may be that a critical phase of matrix formation or calcification is occurring during this period of life and that, once interrupted, this cannot be repaired by subsequently raised serum calcium levels. It is interesting that in most cases the central and lateral incisor crowns are spared, though examination of the root surfaces or microstructure of hard tissues has not yet been possible. The clinical crowns of these teeth may be unaffected in some instances because they are completed before those of the molars and canines (Orban, 1962) and therefore calcification has ceased before the onset of hypocalcaemia.

The incidence of severe caries in these children may be related to a number of factors. Epidemiological studies by Winter, Hamilton, and James (1966) and Winter et al. (1971a, b) have suggested that prematurity of birth, illness during early years of life, and prolonged bottle feeding are causally related to the prevalence of rampant caries in the preschool child. These reports have shown that, in the London Borough of Camden, more caries was found among children who had been bottle fed at some time than among those who had never been bottle fed. No relation was noted between caries prevalence and the age at which bottle feeding started; however, there was a significant association between caries experience and the duration of the use of a feeding bottle. It is reasonable to suppose that defects of structure would make the teeth of children who have suffered symptomatic hypocalcaemia more vulnerable to all these aetiological factors associated with caries. Also, it is of interest from the study reported here that, in some instances, certain types of bottle feeds in the early days of infancy may have an association with asymptomatic hypocalcaemia and the subsequent development of dental defects. Abnormalities of enamel formation are a frequent finding in prematurity (Miller and Forrester, 1959), in association with general systemic disturbances (Sarnat and Schour, 1941, 1942), and occasionally in a rare

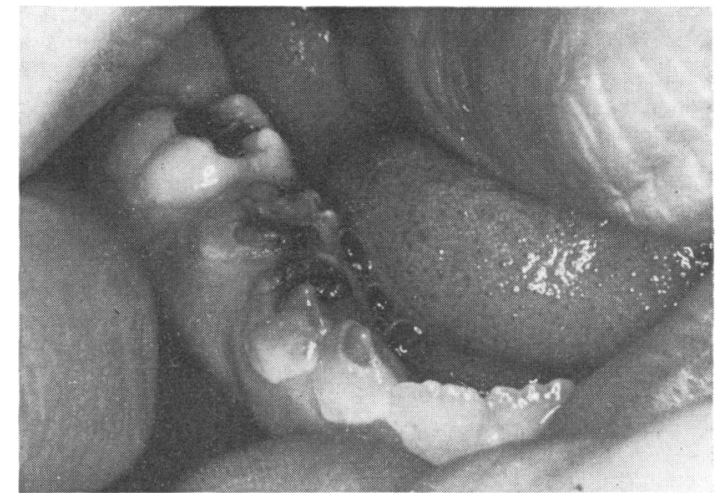

FIG. 2.-Enamel hypoplasia in an 8-year-old boy with congenital hypoparathyroidism.

inherited disorder (amelogenesis imperfecta). Descriptions of these lesions do not resemble the dental changes that follow hypocalcaemic tetany. On the other hand, the dental lesions of congenital hypoparathyroidism (Riley, 1969) (Fig. 2) are virtually identical to those described herein. Presumably, the dental lesions of congenital hypoparathyroidism are also related to low calcium, and possibly high phosphate levels in the serum during a sensitive period of enamel calcification.

\section{REFERENCES}

Miller, J., and Forrester, R. M. (1959). Neonatal enamel hypoplasia. Associated with haemolytic disease and with prematurity British Dental fournal, 106, 93.

Orban, B. J. (1962). Oral Histology and Embryology, 5th ed. Ed. by Harry Sicher. Mosby, St. Louis.

Riley, D. J. (1969). Dental changes in patients with idiopathic hypoparathyroidism. Fournal of Oral Surgery, 27, 44.

Sarnat, B. G., and Schour, I. (1941). Enamel hypoplasia (chronologic enamel aplasia) in relation to systemic disease. A chronologic, morphologic and etiologic classification. Fournal of the American Dental Association, 28, 1989.

Sarnat, B. G., and Schour, I. (1942). Enamel hypoplasia (chronologic enamel aplasia) in relation to systemic disease. A chronologic, morphologic and etiologic classification. Fournal of the American Dental Association, 29, 67.

Winter, G. B., Hamilton, M. C., and James, P. M. C. (1966). Role of the comforter as an aetiological factor in rampant caries of the deciduous dentition. Archives of Disease in Childhood, 41, 207.

TABLE III

Infants with neonatal tetany (Charing Cross Hospital)

\begin{tabular}{|c|c|c|c|c|c|c|}
\hline Case no. & 19 & 20 & 21 & 22 & 23 & 24 \\
\hline $\begin{array}{l}\text { Feed } \\
\text { Plasma calcium }(\mathrm{mg} / 100 \mathrm{ml}) \\
\text { Plasma phosphorus }(\mathrm{mg} / 100 \mathrm{ml}) \\
\text { Age at time of convulsion }(\mathrm{dy}) \\
\text { Dental enamel }\end{array}$ & $\begin{array}{c}\text { Dextrose } \\
\begin{array}{c}7 \cdot 0 \\
\frac{1}{-} \\
\text { Normal }\end{array}\end{array}$ & $\begin{array}{c}\text { SMA } \\
\frac{6 \cdot 4}{4} \\
\text { Hypoplasia }\end{array}$ & $\begin{array}{c}\text { Regal } \\
\\
6 \cdot 2 \\
9 \cdot 2 \\
7 \\
\text { Hypoplasia }\end{array}$ & $\begin{array}{c}\text { National } \\
\text { Dried Milk } \\
6 \cdot 6 \\
11 \cdot 2 \\
8 \\
\text { Hypoplasia }\end{array}$ & $\begin{array}{l}\text { Carnation } \\
\begin{array}{l}5 \cdot 7 \\
\frac{7}{7} \\
\text { Hypoplasia }\end{array}\end{array}$ & $\begin{array}{l}\text { Cow and Gate } \\
\begin{array}{l}6 \cdot 9 \\
2 \\
\text { Slight } \\
\text { hypoplasia }\end{array}\end{array}$ \\
\hline
\end{tabular}


Winter, G. B., Rule, D. C., Mailer, G. P., James, P. M. C,. and Gordon, P. H. (1971a). The prevalence of dental caries in pre-school children aged 1 to 4 years. Part 1. Aetiological factors. British Dental fournal, 130, 271.

Winter, G. B., Rule, D. C., Mailer, G. P., James, P. M. C., and Gordon, P. H. (1971b). The prevalence of dental caries in pre-school children aged 1 to 4 years. Part 2. Additional aetiological factors. British Dental fournal, 130, 434.

\section{Addendum}

Since this present study was completed, a retrospective survey at Charing Cross Hospital of children who had had hypocalcaemic convulsions was undertaken by

Miss L. Davis Reynolds and Mr. J. Bennett. 6 children over the age of 2 were examined. The results are summarized in Table III. It is very interesting that in the infant where hypocalcaemia occurred in the first day of life the enamel was normal and in the patient who had symptoms in the second day of life, the enamel lesions were slight, in contrast to the severe degree of enamel hypoplasia in the 4 infants between days 4 and 8 .

Correspondence to Dr. L. Stimmler, Guy's Hospital, London SE1 9RT. 